\title{
Polish Theriological Bibliography, 1985
}

\author{
Polska Bibliografia Teriologiczna, 1985
}

Польская Териологическая Библиография

Michalina PUCEK

I. List of periodical titles and their abbreviations . . . . . . . 557

II. Titles of papers not included in previous issues for $1984 .{ }_{0} . \quad . \quad 558$

III. Titles of papers published in 1985

IV. Subject index publist
0 . General literature
1. Evolution and Genetics
2. Morphology
4. Reproduction, Sex, Hybridisation
5. Development
6. Ecology, Biology and Conservancy
7. Distribution, Fauna and Systematics, Palaeontology
8. Parasites, Epidemiology and Pathology

\section{LIST OF PERIODICAL TITLES AND THEIR ABBREVIATIONS}

Acta biol. cracov., zool.

Acta physiol, pol. Acta theriol.

Acta zool. cracov.

Acta Zool. Fennica

Anat. Anz.

Archeol. pol.

Bats

Chrońmy Przyr. ojez.

Comp. Biochem. Physiol. A

Deer

Experientia

Folia biol.

Folia morph.

Folia quatern.

Gen. pol.

J. Appl. Ecol.

Kronika Wlkp.

Mammalia

Med. wet.

Nyctalus

PWRiL
- Acta Biologica Cracoviensia, seria Zoologia, Kraków

- Acta Physiologica Polonica, Warszawa

- Acta Theriologica, Białowieża-Warszawa

- Acta Zoologica Cracoviensia, Kraków

- Acta Zoologica Fennica, Helsinki

- Anatomischer Anzeiger, Jena

- Archeologia Polski, Wrocław

- Bats, Newsletter of Bat Conservation International Milwaukee

- Chrońmy Przyrodę Ojczystą, Kraków

- Comparative Biochemistry and Physiology, A. Physiology, Oxford

- Deer, Journal of the British Deer Society, Southampton

- Experientia, Basel

- Folia Quaternaria, Kraków

- Folia Morphologica, Warszawa

- Folia Quaternaria, Kraków

- Genetica Polonica, Poznań

- Journal of Applied Ecology, Oxford

- Kronika Wielkopolski, Poznań

- Mammalia, Paris

- Medycyna Weterynaryjna, Lublin

- Nyctalus, Berlin

- Państwowe Wydawnictwo Rolne i Leśne, Warszawa 
Parki nar. Rez. Przyr.

Pol. ecol. Stud.

Pol. Pismo entomol.

Pr, Kom, archeol. PAN, Wrocław

Pr. nauk. IOR

Proc. Helminthol. Soc. Wash.

Prz. zool

Rev. Ecol. (Terre Vie)

Roczn. Akad. roln. Poznań, archeozool.

Roczn. Akad. roln. Poznań, zootechn.

Stud. Ośr. fizjograf.

Symp. zool. Soc. Lond.

J. Jagdwiss.

Zesz. nauk. Filii UW, Biol.

Zool. Pol.

Zwierzęta Lab.
- Parki Narodowe i Rezerwaty Przyrody, Warszawa

- Polish Ecological Studies, Warszawa

- Polskie Pismo Entomologiczne, Wroclaw

- Prace Komisji Archeologicznej, Polska Akademia Nauk, oddział we Wrocławiu, Wrocław

- Prace Naukowe Instytutu Ochrony Roślin, Poznań

- Proceedings of the Helminthological Society of Washington, Lawrence

- Przegląd Zoologiczny, Wrocław

- Revue d'Ecologie (La Terre et la Vie), Paris

- Roczniki Akademii Rolniczej w Poznaniu, seria Archeozoologia, Poznań

- Roczniki Akademii Rolniczej w Poznaniu, seria Zootechnika, Poznań

- Studia Ośrodka Dokumentacji Fizjograficznej, Wroclaw

- Symposia of the Zoological Society of London, London

- Zeitschrift für Jagdwissenschaft, Hamburg

- Zeszyty Naukowe Filii Uniwersytetu Warszawskiego w Białymstoku, Nauki Matem.-Przyr., dzial B - Prace Biologiczne

- Zoologica Poloniae, Wrocław

- Zwierzęta Laboratoryjne, Warszawa

- książki, books, книги

\section{TITLES OF PAPERS NOT INCLUDED IN PREVIOUS ISSUES FOR 1984}

BOBEK B., BOYCE M. S. KOSOBUCKA M. [Dept. Anim. Ecol., Jagiell. Univ., Karasia 6, 30-060 Kraków]: Factors affecting red deer (Cervus elaphus) population density in southeastern Poland. J. Appl. Ecol. 21: 881-890.

- BOBEK B., MOROW K. \& PERZANOWSKI K.: Ekologiczne podstawy lowiectwa - [Ecological basis of game management]. PWRiL, Warszawa, 314 pp. [In Polish.]. CHWEDEŃCZUK K. [Warsaw Zool. Garden, Ratuszowa 1/3, 03-461 Warszawa]: Obserwacje nad zachowaniem się fok szarych, Halichoerus grypus (Fab.) w Warszawskim ZOO - Studies on the behaviour of grey seals, Halichoerus grypus (Fab.) in Warsaw ZOO. Prz. zool. 28, 1: 93-97 [In Polish with English summ.].

FRACKOWIAK H. [Dept. Anim. Anat., Agric. Acad., Wojska Polskiego 71c, 60-625 Poznań]: The sinuses of the dura mater in bovine fetuses. Folia morph. 43, 4: 303-310 [Polish summ.].

GAWLIKOWSKI J. (1), see STĘPIEN J. \& GAWLIKOWSKI J. (1)

GAWLIKOWSKI J. (2), see STĘPIEN J. \& GAWLIKOWSKI J. (2)

GAWLIKOWSKI J. \& STEPIEN J. (1) [Dept. Anim Anat., Agric. Acad., Doktora Judyma 14, 71-466 Szczecin]: Zwierzęce szczątki kostne ze stanowiska $1 \mathrm{w}$ Stargardzie Szczecińskim - Animal bone remains from site no 1 in Stargard Szczeciński. Roczn. Akad. roln. Poznań 154, archeozool. 9: 19-34 [In Polish with English and Russ. summ.].

GAWLIKOWSKI J. \& STEPIEN J. (2): Zwierzecy materiał kostny $\mathrm{z}$ wykopalisk archeologicznych na wzgórzu klasztornym w Cedynii - Animal bone material from the archaeological excavations on the Monastery Hill in Cedynia. Roczn. 
Akad. roln. Poznań 154, archeozool. 9: 3-17 [In Polish with English and Russ. summ.J.

GRZYBIAK M., see SZOSTAKIEWICZ-SAWICKA H. \& GRZYBIAK M.

KNASIECKA V. [Dept. Anim. Anat., Agric. Acad., Wojska Polskiego 71c, 60-625 Poznań]: Variations in the origin of the caudal phrenic and cranial abdominal arteries in silver fox, Vulpes vulpes fulva (Desmarest, 1820). Folia morph. 43, 4: 349-353 [Polish summ.].

KOBRYN H. \& SERWATKA S. [Inst. Anim. Physiol., Warsaw Agric. Univ., Nowoursynowska 166, 02-766 Warszawa]: Szczątki kostne świni domowej (Sus scrofa f. domestica L., 1758) w materiale wykopaliskowym $\mathrm{z}$ średniowiecznego grodu w Kaliszu-Zawodziu - Bone remains of domestic pigs (Suc scrofa f. domestica L., 1758) in the excavation material from a mediaeval stronghold in Kalisz-Zawodzie. Archeol. Pol. 29, 2: 415-425 [In Polish with English summ.].

KOBRYŃ H., SERWATKA S. \& SWIEŻYŃSKI K., Charakterystyka morfologiczna szczątków bydła $z$ wykopalisk archeologicznych na terenie średniowiecznego grodu w Kaliszu-Zawodziu - Morphological characteristics of bovine remains from the archaeological excavations in the mediaeval stronghold in Kalisz-Zawodzie. Archeol. Pol. 29, 2: 399-413 [In Polish with English summ.].

KOSOBUCKA M., see BOBEK B. et al.

KUBASIK-JURANIEC J. \& SZOSTAKIEWICZ-SAWICKA H. [Dept. Anat., Med. Acad., Dębinki 1, 80-211 Gdańsk]: Variations of diaphragmatic crura in Primates. Folia morph. 43, 4: 343-348 [Polish summ.].

LASOTA-MOSKALEWSKA A. [Ateliers Conserv. Cultural Propert., Senatorska 14, 00-950 Warszawa]: Ocena archeozoologiczna materialu kostnego z wczesnośredniowiecznego grodziska w Tykocinie - Archaeozoological study of the bone material in the early mediaeval castle in Tykocin. Archeol. Pol. 29, 2: 245-265 [In Polish with English summ.].

MOLENDA O. (1) [Dept. Anim. Anat., Agric. Acad., Kożuchowska 1-3, 51-631 Wrocław]: Szczątki kostne zwierząt $\mathrm{z}$ wczesnośredniowiecznej Rzymówki, gmina Złotoryja, województwo legnickie - Animal bone remains from the early medieval Rzymówka, commune Złotoryja, province Legnica. Roczn. Akad. roln. Poznań 154, archeozool. 9: 55-65 [In Polish with English and Russ. summ.].

MOLENDA O. (2): Szczątki kostne świni (Sus scrofa f. domestica) z wczesnośredniowiecznego Ostrówka w Opolu - Bone remains of swine (Sus scrofa f. domestica) from early medieval Ostrówko in Opole. Roczn. Akad. roln. Poznań 154, archeozool. 9: 67-86 [In Polish with English and Russ. summ.].

MOROW K., see BOBEK B. et al.

MORYS J., SEONIEWSKI P. \& NARKIEWICZ O. [Dept. Anat., Med. Acad., Dębinki 1, 80-211 Gdańsk]: Thalamic projections to the insular cortex in the cat. Folia morph. 43, 4: 395-399 [Polish summ.].

NARKIEWICZ O., see MORYS J. et al.

OSEMLAK J., see SIWEK R. \& OSEMLAK J.

PERZANOWSKI K., see BOBEK B. et al.

POSPIESZNY N. [Dept. Anim. Anat., Agric. Acad, Kożuchowska 1-3, 51-631 Wrocław]: The relationship between the nervus accessarius and the ganglion distale nervi vagi in the sheep during the prenatal period. Anat. Anz. 157, 2: 127-135 [In German].

- PUCEK Z. [Mammals Res. Inst., P. A. Sci., 17-230 Białowieża]: The European bison, current state and problems of management. In "Conservation, science and society". Contributions to the First International Biosphere Reserve Congress, Minsk, Byelorussia, USSR, 26 September -2 October 1983. Natural Resources Research 21, 2: 276-282, UNESCO-UNEP, Paris.

ROMANOWSKI J. [Inst. Ecol., P. A. Sci., Dziekanów Leśny, 05-092 Łomianki]: Występowanie wydry Lutra lutra (Linnaeus, 1758) w Polsce w świetle wyników 
ankiety dla myśliwych - The occurrence of the otter Lutra lutra (Linnaeus, 1758) in Poland in the light of inquiry to hunters. Prz. zool. 28, 1: 87-91 [In Polish with English summ.].

SERWATKA S. (1), see KOBRYŃ H. et al.

SERWATKA S. (2), see KOBRYŃ H. \& SERWATKA S.

SIWEK R. \& OSEMLAK J. [Clinic Pediatr. Surg., Med. Acad., Staszica Str. 11, 20-081 Lublin]: Relationships between arteries and bile ducts in Cercopithecus aethiops. Folia morph. 43, 4: 355-361 [Polish summ.].

SEONIEWSKI P., see MORYS J. et al.

SOBOCIŃSKI M. (1) [Inst. Appl. Zool., Agric. Acad., Wojska Polskiego 71c, 60-625 Poznań]: Szczątki kostne zwierząt z osady mezolityczno-neolitycznej w Dabkach, gmina Darłowo - Animal bone remains from a mesolithico-neolithic settlement in Dąbki, commune Darłowo. Roczn. Akad. roln. Poznań 154, archeozool. 9: 101-128 [In Polish with English and Russ. summ.].

SOBOCIŃSKI M. (2): Zwierzęce szczątki kostne z obiektów kultury ceramiki wstęgowej w Zalęcinie i Żukowie województwo szczeciŕskie - Animal bone remains from Linear Bend Pottery objects in Zalęcino and Żuków, Province Szczecin. Roczn. Akad. roln. Poznań 154, archeozool. 9: 87-99 [In Polish with English and Russ. summ.].

SOBOCIŃSKI M. \& SUCHOWERA-KOBRYŃSKA M.: Szczątki kostne świni z osad kultury przeworskiej na Kujawach - Pig bone remains from settlements of Przeworsk culture in Kujawy region. Roczn. Akad. roln. Poznań 154, archeozool. 9: 129-140 [In Polish with English and Russ. summ.].

SOBOCIŃSKI M. \& SWIDERSKA W.: Szczątki kostne konia z osad kultury przeworskiej na Kujawach - Horse bone remains from settlements of Przework Culture Kujawy region. Roczn. Akad. roln. Poznań 154, archeozool. 9: 141-160 [In Polish with English and Russ. summ.].

STEFANOWSKI T. [Dept. Anim. Anat., Agric.-Techn. Acad., 10-957 Olsztyn-Kortowo]: The left cranial vena cava in dog. Folia morph. 43, 4: 327-330 [Polish summ.].

STĘPIEN J. (1), see GAWLIKOWSKI J. \& STĘPIEN J. (2)

STĘPIEN J. (2), see GAWLIKOWSKI J. \& STĘPIEN J. (2)

STEPIEN J. \& GAWLIKOWSKI J. (1) [Dept. Anim. Anat., Agric. Acad., Doktora Judyma 14, 71-466 Poznań]: Szczątki kostne zwierzat z archeologicznego stanowiska w Eobrzanach - Bone remains of animals from the archaeological site in Łobrzany. Roczn. Akad. roln. Poznań 154, archeozool. 9: 169-176 [In Polish with English and Russ. summ.].

STĘPIEN J. \& GAWLIKOWSKI J. (2): Zwierzęcy materiał kostny $\mathrm{z}$ wczesnośredniowiecznej osady (stanowisko 3) w Derczewie - Animal bone material from the early medieval in Derczewo. Roczn. Akad. roln. Poznań 154, archeozool. 9: 161-168 [In Polish with English and Russ. summ.].

SUCHOWERA-KOBRYŃSKA M., see SOBOCIŃSKI M. \& SUCHOWERA-KOBRYŃSKA M.

SZOSTAKIEWICZ-SAWICKA H., see KUBASIK-JURANIEC J. \& SZOSTAKIEWICZ-SAWICKA $\mathrm{H}$.

SZOSTAKIEWICZ-SAWICKA H. \& GRZYBIAK M. [Dept. Anat., Med. Acad., Dębinki 1, 80-211 Gdańsk]: The structure of some viscera in relation to the shape of the thorax in Primates. Folia morph. 43, 4: 331-336 [Polish summ.].

SWIDERSKA W., see SOBOCIŃSKI M. \& SWIDERSKA W.

SWIEŻYŃSKI K., see KOBRYN H. et al.

WIERzBOWSKA T. [Inst. Computer Sci., P. A. Sci., Pałac Kultury i Nauki, 00-901 Warszawa]: Sample size in the problem of statistical estimation of home range size in small rodents. Pol. ecol. Stud. 9(1983), 4: 507-563 [Polish summ.]. 


\section{TITLES OF PAPERS PUBLISHED IN 1985}

ADAMCZYK K., see CHEŁKOWSKA H. et al

ALEXANDROWICZ S. W., NADACHOWSKI A., RYDLEWSKI J., VALDE-NOWAK P. \& WOEOSZYN B. W. [Inst. Syst. \& Exp. Zool., P. A. Sci., Sławkowska 17, 31-016 Kraków]: Subfossil fauna from a cave in the Sobczański Gully (Pieniny Mts., Poland). Folia quatern. 56: 57-78 [Polish summ.].

BEAUCOURNU J. C. \& KOWALSKI K. Caenopsylla eremita sp. n. (Siphonaptera: Leptopsyllidae) puce de Massoutiera mzabi (Lataste 1881) (Rodentia: Ctenodactylidae) au Hoggar (Algérie). Acta zool. cracov. 28, 2: 159-168 [Polish summ.].

BIERNACKA J., see TOPIŃSKI P. \& BIERNACKA J.

BOBEK B., see KINGSTON N. \& BOBEK B.

BUCHALCZYK T., see WOLSAN M. et al.

BUJALSKA G. (1) [Inst. Ecol., P. A. Sci., Dziekanów Leśny, 05-150 Łnmianki]: Fluctuations in an island bank vole population in the light of the study on its organization. Acta theriol. 30, 1: 3-49 [Polish summ.].

BUJALSKA G. (2): Population dynamics of an island population of Clethrionomys glareolus. Acta Zool. Fennica 173: 29-34.

BUSZKO S., see RUPRECHT A. L. \& BUSZKO S.

CHEŁKOWSKA H., WALKOWA W. \& ADAMCZYK K. [Inst. Ecol., P. A. Sci., Dziekanów Leśny, 05-092 Łomianki]: Spatial relationships in sympatric population of the rodents: Clethrionomys glareolus, Microtus agrestis and Apodemus agrarius. Acta theriol., 30, 2: 51-78 [Polish summ.].

CHRZANOwSKA W. (1) [Dept. Anim. Anat., Agric. Acad., Kożuchowska 1-3, 51-631 Wrocław]: Dzikie ssaki Sląska w pradziejach w świetle kostnych materiałów wykopaliskowych - Wild mammals of Silesia in primaeval in the light of bone excavatory materials. In "Dawna fauna Sląska w świetle badań archeologicznych", Ed. P. Wyrost, Pr. Kom. archeol. PAN Wrocław, 3: 21-32 [In Polish with English summ.].

CHRZANOWSKA W. (2), see WYROST P. \& CHRZANOWSKA W. (1)

CHRZANOWSKA W. (3), see WYROST P. \& CHRZANOWSKA W. (2)

CHRZANOWSKA W. (4), see WYROST P. \& CHRZANOWSKA W. (3)

CHUCHLA M., see MICHALCZYK K. et al.

CYGAN T. [Dept. Anim. Ecol., Jagiell. Univ., Karasia 6, 30-060 Kraków]: Seasonal changes in thermoregulation and maximum metabolism in the yellow-necked field mouse. Acta theriol. 30, 4: 115-130 [Polish summ.].

CZECZUGA B. [Dept. Biol., Med. Acad., Kilińskiego 1, 15-230 Białystok]: The carotenoid content of mammals. V. The European hare (Lepus europaeus Pallas 1778). Zool. Pol. 32, 1-2: 83-94 [Polish and Russ. summ.].

CZECZUGA B. \& RUPRECHT A. L.: Contents of carotenoids in mammals. III. Carotenoids in specimens of six species of Vespertilionidae. Nyctalus 2, 2: 186-190 [German summ.].

CZEKAŃSKI M., KAPEON J., RYNKOWSKA E., WALICKI J. \& WALICKI K.: Obserwacje nietoperzy $w$ rezerwacie faunistycznym Nietoperek - Observations on the bats of the "Nietoperek" faunistic reserve. Chronmy Przyr. ojcz. 41, 3: 59-63 [In Polish].

DEMIASZKIEWICZ A. [Inst. Parazyt. P. A. Sci., Pasteura 3, 00-973 Warszawa]: Elaphostrongyloza - nowa parazytoza jeleniowatych w Polsce - Elaphostrongylosis - a new parasitic disease in Poland. Med. wet. 41, 10: 616-618 [In Polish with English \& Russ. summ.].

DOBROWOLSKA A. \& WOLAÑSKA L. [Dept. Vertebr. Anim. Physiol., Inst. Zool., Warsaw Univ., Żwirki i Wigury 93, 02-089 Warszawa]: Variability of trans- 
ferrin in field mice from an urban park, suburban island and field populations. Acta theriol. 30, 21: 327-335 [Polish summ.].

FEDYK S., see WOJCIK J. M. \& FEDYK S.

FEDYK S. \& RUPRECHT A. L. [Lab. Gen. \& Evol., Dept. Biol., Warsaw Univ. Div., Sosnowa 64, 17-887 Bialystok]: Chromosomes of some species of vespertilionid bats. III. Banded chromosomes of Vespertilio murinus L., 1758. Nyctalus 2, 2: 119-126 [German summ.].

GALERT D. [Inst. Biol., Pedagogic. Coll., Żołnierska 14, 10-561 Olsztyn]: Morphology and topography of substantia nigra in Insectivora. Folia morph. 44, 3-4: 186-193 [Polish summ.].

GAŻDZIK T., KAMINNSKI M., WĄGIEL J. \& KOWALSKA G. [Dept. Hist. \& Embr., Med. Acad., Medyków 12, 40-752 Katowice]: Morphometry of the rat testis in postnatal period. Folia morph. 44: 1: 20-23 [Polish summ.].

GĘBCZYNSSKA Z., see GĘBCZYŃSKI M. \& GĘBCZYŃSKA Z.

GĘBCZYŃSKI M. [Dept. Biol., Warsaw Univ. Div., Sosnowa 64, 15-887 Białystok]: Temporal patterns of genetic variation in a population of Sorex minutus. Acta Zool. Fennica 173: 241-242.

GĘBCZYNNSKI M. \& GĘBCZYŃSKA Z.: Parental energy investement into offspring growth in the root vole. Zesz. nauk. Filii UW 48, Biol. 10: 99-104 [Polish summ.]. GIENC J. \& KUDER T. [Dept. Anat., Pedag. Coll., Rewolucji Październikowej 33, 24-518 Kielce]: Relations between maxillary artery and the otic ganglion. Folia inorph. 44, 3-4: $212-215$ [Polish summ.].

GINTER B., see BOCHENSKI Z. et al.

GIZA A., see SIKORSKA-PIWOWSKA Z. et al.

GLIWICZ J. [Dept. Wildl. Manage., Forestry Fac., Warsaw Agric. Univ., Rakowiecka 26/30, 02-528 Warszawa]: Rodent community of dry African savanna: population study. Mammalia 49, 4: 509-516.

GOZLINSKI H., see GROMADZKA-OSTROWSKA J. et al.

GRACZYK R. [Inst. Appl, Zool, Agric. Acad, Wojska Polskiego 71c, 60-625 Poznań]: Restytuacja bobra europejskiego (Castor fiber Linnaeus, 1758) w Wielkopolsce - [Restitution of the European beaver (Castor fiber Linnaeus, 1758) in Wielkopolska region]. Kronika Wlkp. 4(39): 107-134 [In Polish].

GRĄBCZEWSKA E., MASLIŃSKI W. \& RYŻEWSKI J. [Dept. Pathophysiol., Reumatol. Inst., Spartańska 1, 02-673 Warszawa]: Muscarinic receptors of rat lymphocytes - differences in young and old animals. Acta physiol. pol. 36, 4: 276-281.

GRODZIŃSKI W. [Dept. Ecosyst. Stud., Jagiell. Univ., Karasia 6, 30-060 Kraków]: Ecological energetics of bank voles and wood mice. Symp. zool. Soc. Lond. 55: 169-192.

GROMADZKA J., see SZYLARSKA-GOŹDŹ E. \& GROMADZKA J.

GROMADZKA-OSTROWSKA J., see JAKUBOW K. et al.

GROMADZKA-OSTROWSKA J. \& ZALEWSKA B. [Physiol. Lab., Warsaw Zool. Garden, Ratuszowa 1/3, 03-461 Warszawa]: Seasonal fluctuations in plasma protein fraction levels of chinchillas (Chinchilla laniger, M.). Comp. Biochem. Physiol. A $80,2: 215-224$.

GROMADZKA-OSTROWSKA J., ZALEWSKA B., JAKUBOW K. \& GOŹLIŃSKI H.: Three-year study on trace mineral concentration in the blood plasma of shetland pony mares. Comp. Biochem. Physiol. A 82, 3: 651-660.

GROMADZKA-OSTROWSKA J., ZALEWSKA B. \& SZYLARSKA-GOŹDŹ E.: Peripheral plasma progesterone concentration and haematological indices during normal pregnancy of chinchillas (Chinchilla laniger, M.). Comp. Biochem. Physiol. A $82,3: 661-665$.

HAITLINGER R. [Onst. Biol. Fund. Anim, Prod., Agric. Acad., Cybulskiego 20, 50-205 Wrocław]: Roztocze (Acari: Podapolipidae, Parasitidae, Eviphidae, Macro- 
chelidae, Ascidae) nowe lub rzadkie dla fauny Polski, zebrane $\mathrm{z}$ chrząszczy (Coleoptera) i gryzoni (Rodentia) - Mites (Acari: Podapolipidae, Parasitidae, Eviphidae, Macrochelidae, Ascidae) new or rare in the Polish fauna, collected on beetles (Coleoptera) and rodents (Rodentia). Pol. Pismo entomol. 55, 3: 611-614 [In Polish with English summ.].

HAITLINGER R. \& RUPRECHT A. R.: Stawonogi zebrane na nietoperzach z Kujaw (Acari i Siphonoptera) - Arthropods collected from Kujawian bats (Acari and Siphonaptera). Pol. Pismo entomol. 55, 3: 615-618 [In Polish with English summ.].

HARMATA W. (1) [Dept. Psychol. \& Ethol. Anim., Jagiell. Univ., Karasia 6, 30-060 Kraków]: Rezerwat Nietoperek unikatem na skalę światową - "Nietoperek" a nature reserve unique on a global scale. Chrońmy Przyr. ojcz. 41, 3: 21-27 [In Polish with English summ.].

HARMATA W. (2): The length of avakening time from hibernation of three species of bats. Acta theriol. 30, 20: 321-323.

HARMATA W. (3): Zmiany $\mathrm{w}$ chiropterofaunie i awifaunie regionu chrzanowskiego wywołane działalnością człowieka - Changes of bat and birds fauna in Chrzanów region. Studia Ośr. fizjogr. 13: 197-202 [In Polish with English summ.].

JACZEWSKI Z. (1) [Inst. Gen. \& Anim. Breed., P. A. Sci., Res. St. Popielno, 12-222 Wejsuny]: Hormonal regulation of antler casting in red deer. In "Functional morphology in vertebrates", Eds H. R. Duncker \& G. Fleischer, Fortschritte Zool. 30: 167-171, G. Fischer Verl., Stuttgart.

JACZEWSKI Z. (2), see OSWALD C. \& JACZEWSKI Z.

JACZEWSKI Z. \& OSWALD C.: Observations on the international formulas for the measurement and evaluation of marsh deer (Blastocerus dichotomus Illiger, 1815) and Schomburgk's deer (Cervus schomburgki Blyth, 1863). Z. Jagdwiss. 31, 3: 175-184 [In German with English and French summ.].

JAKUBOW K., see GROMADZKA-OSTROWSKA J. et al.

JAKUBOW K., GROMADZKA-OSTROWSKA J. \& ZALEWSKA B. [Physiol. Lab., Warsaw Zool. Garden, Ratuszowa 1/3, 03-461 Warszawa]: Age and physiological status influence on plasma protein fraction levels in chinchillas (Chinchilla laniger, M.). Comp. Biochem. Physiol. A 80, 4: 599-607.

JATCZAK B., see SZTEYN S. et al.

KAlETA T. [Inst. Breed. \& Techn. Anim. Prod., Warsaw Agric. Univ., Przejazd 4, 03-840 Brwinów]: Społeczna strategia i systemy komunikacji niewerbalnej w rodzinie Canidae (na przykładzie wybranych gatunków) - The social strategy and non-verbal communication systems in the family Canidae (concerning selected species). Prz. zool. 29, 3: 355-359 [In Polish with English summ.].

KAMINSKI M., see GAŹDZIK T. et al.

KANIA B. F., SUMIŃSKI E. \& KOSSAKOWSKI J. [Dept. Pharmacol. Toxicol., Warsaw Agric. Univ., Nowoursynowska 166, 02-766 Warszawa]: An effective immobilizing agent for hybrids of European bison and domestic cattle. Acta theriol. 30, 27: 435-444 [Polish summ.].

KAPŁON J., see CZEKAŃSKI M. et al.

KASZUBA S. \& SCHMIDT K. [Młyńska 17/117, 81-063 Gdynia]: Autointrodukcja norki amerykańskiej Mustela vison w rezerwacie faunistycznym Jezioro Drużno Autointroduction of the mink Mustela vison in the "Lake Drużno" nature reserve. Chrońmy Przyr. ojcz. 41, 2: 68-71 [In Polish].

KIERKOWSKA M., see SOBOCIŃSKI M. \& KIERKOWSKA M.

KINGSTON N. \& BOBEK B.: A trypanosome in roe deer Capreolus capreolus in Southern Poland. Proc. Helminthol. Soc. Wash. 52, 1: 143.

KLEVEZAL G. A., PUCEK M. \& MALAfEeVA E. P. [Inst. Develop. Biol., USSR Acad. Sci., 26 Vavilov Str., 117334 Moscow, USSR]: Differentiation of seasonal generations of field voles on bone adhesion lines. Acta theriol. 30, 23: 349-368 [Polish summ.]. 
KOBRYN H., see LASOTA-MOSKALEWSKA A. et al.

KOBRYN H. \& KOBRYÑCZUK F. [Dept. Anim. Anat., Warsaw Agric. Univ., Nowoursynowska 166, 02-776 Warszawa]: Próba zastosowania funkcji dyskryminacyjnej do różnicowania wielkości kości konia w materiałach archeozoologicznych A trial of discriminant function application for differentiation of the size of equine bones in archaeozoological finds. Archeol. Pol. 30, 1: 7-15 [In Polish with English summ.].

KOBRYÑCZUK F. (1) [Dept. Anim. Anat., Warsaw Agric. Univ., Nowoursynowska 166, 02-776 Warszawa]: The influence of inbreeding on the shape and size of the skeleton of the European bison. Acta theriol. 30, 25: 379-422 [Polish summ.].

KOBRYŃCZUK F. (2), see KOBRYŃ H. \& KOBRYŃCZUK F.

KOSSAKOWSKI J., see KANIA B. F. et al.

KOT K. [Dept. Anim. Reprod., Agric. Acad., Mickiewicza 24/28, 30-059 Kraków]: Obserwacje nad morfologiczną budową światła macicy klaczy - Observations on the morphology of the mare uterus. Med. wet. 41, 5: 304-308 [In Polish with English and Russ. summ.].

KOWALSKA G., see GAZ̃DZIK T. et al.

KOWALSKI K. (1) [Inst. Syst. \& Exp. Zool., P. A. Sci., Sławkowska 17, 31-016 Kraków]: Annual cycle of reproduction in Apodemus sylvaticus in Algeria. Acta Zool. Fennica 173: 85-86.

KOWALSKI K. (2), see BEAUCOURNU J. C. \& KOWALSKI K.

KOZAKIEWICZ A. [Dept. Zool. \& Ecol., Inst. Zool., Warsaw Univ., Krakowskie Przedmieście 26/28, 00-927 Warszawa]: Lakeside communities of small mammals. Acta theriol. 30, 9: 171-191 [Polish summ.].

KOZAKIEWICZ M. [ Dept. Zool. \& Ecol., Inst. Zool., Warsaw Univ., Krakowskie Przedmieście 26/28, 00-927 Warszawa]: The role of habitat isolation in formation of structure and dynamics of the bank vole population. Acta theriol. 30, 10: 193-209 [Polish summ.].

KOZŁOWSKI J. [Inst. Environmental Biol., Jagiell. Univ., Karasia 6, 30-060 Kraków]: Optimization of age at maturity and its morphological consequences in mammals. Zesz. nauk. Filii UW 48, Biol. 10: 1-9 [Polish summ.].

KOZ£OWSKI J. K., see BOCHEŃSKI Z. et al.

KOZŁOWSKI P., see SIKORSKA-PIWOWSKA Z. et al.

KROL E. [Dept. Anim. Ecol., Jagiell. Univ., Karasia 6, 30-060 Kraków]: Reproductive energy budgets of hedgehogs during lactation. Zesz. nauk. Filii UW 48, Biol. 10: 105-117 [Polish summ.].

KRYST-WIDŻGOWSKA T., see SIKORSKA-PIWOWSKA Z. et al.

KRZANOWSKI A. [Inst. Syst. \& Exp. Zool., P. A. Sci., Sławkowska 17, 31-016 Kraków]: Poland's bats in trouble. Bats 2, 1: 2-3.

KRZYWIŃSKI A. [Inst. Gen. \& Anim. Breed., P. A. Sci., Res. St. Popielno, 12-222 Wejsuny]: A study in artificial breeding in deer for practical application. Deer 6: $211-213$.

KUBASIK A. \& SzOSTAKIEWICZ-SAWICKA H. [Dept. Norm. Anat., Med. Acad., Dębinki 1, 80-211 Gdańsk]: Some remarks on the general structure of the solitary tract nucleus in rat. Folia morph. 44, 3-4: 194-203 [Polish summ.].

KUDER T. (1) [Dept. Anat., Inst. Biol., Pedagogical Coll., Rewolucji Październikowej 33/35, 25-518 Kielce]: Topography and macroscopic structure of parasympathetic ganglia connected with the trigeminal nerve in midday gerbil (Meriones meridianus - Mammalia: Rodentia). Acta biol. cracov., zool. 27: 61-70.

KUDER T. (2), see GIENC J. \& KUDER T.

KUKWA A., see SIKORSKA-PIWOWSKA Z. et al.

LASKOWSKA-KLITA T., see SŁAWETA R. \& LASKOWSKA-KLITA T. 
LASOTA-MOSKALEWSKA A., KOBRYŃ H. \& SWWIEŻYŃSKI K. [Ateliers Conserv. Cultural Propert., Senatorska 14, 00-950 Warszawa]: Zabytki pochodzenia zwierzęcego $\mathrm{z}$ grobu mezolitycznego w Janisławicach, woj. Skierniewickie - Animal remains in a mesolithic grave in Janislawce, Skierniewice Voivodship. Archeol. Pol. 30, 2: 287-309 [In Polish with English summ.].

LIRO A. [Res. Inst. Environ. Develop., Krzywickiego 9, 02-078 Warszawa]: Variation in weights of body and internal organs of the field mouse in gradient of urban habitats. Acta theriol. 30, 24: 359-377 [Polish summ.].

¿UKASZEWSKA-OTTO H., see SIKORSKA-PIWOWSKA Z. et al.

MAKOWIECKI D. (1) [Dept. Anim. Anat., Agric. Acad., Wojska Polskiego 71c, 60-625 Poznań]: Zwierzęce szczątki z osady neolitycznej w Brąchnówku woj. toruńskie - Animal bone remains from a neolithic settlement in Brąchnówek, Toruń province. Roczn. Akad. roln. Poznań 164, archeozool. 10: 7-18 [In Polish with English and Russ. summ.].

MAKOWIECKI D. (2): Szczątki zwierzęce z osady kultury pucharów lejkowatych $\mathrm{w}$ Podgaju woj. wloclawskie - Bone remains from the period of Funnel Beaker culture in Podgaj, Włocławek province. Roczn. Akad. roln. Poznań 164, archeozool. 10: 19-24 [In Polish with English and Russ. summ.].

MALZAHN E. [Dept. Nat. Protect., Forestry Res. Inst., 17-230 Białowieża]: Generation differences in the postnatal development of small mammals. Zesz. nauk. Filii UW 48, Biol. 19: 43-50 [Polish summ.].

MASLIŃSKI W., see GRĄBCZEWSKA E. et al.

MEZCZYŃSKI S. (1) [Dept. Comp. Anat. \& Anthrop., Univ. M. Curie-Skłodowska, Akademicka 19, 20-033 Lublin]: Czy suseł moręgowany, Spermophilus citellus Linnaeus, 1766, występuje jeszcze w Polsce? - Does the European ground squirrel, Spermophilus citellus Linnaeus, 1766, still occur in Poland? Prz. zool. 29, 4: 521-526 [In Polish with English summ.].

MECZYŃSKI S. (2): Problemy ochrony susła perełkowanego Spermophilus suslicus w Polsce - The spotted souslik, Spermophilus suslicus, and the problems of its protection in Poland. Chrońmy Przyr. ojcz. 41, 2: 26-35 [In Polish with English summ.].

MICHALCZYK K., MIERZWA A., MIERZWA J. \& CHUCHLA M. [Dept. Norm. Anat., Med. Acad., Powstańców Wlkp. 72, 70-111 Szczecin]: Arteries of the kidney in domestic sheep. Folia morph. 44, 3-4: 232-240 [Polish summ.].

MICHALSKI J. \& REMI J. [Dept. Forest. Entomol., Agric. Acad., Wojska Polskiego 71c, 60-625 Poznań]: O możliwości dziedziczenia deformacji parostków sarny (Capreolus capreolus L.) - On possibility of inheriting deformation in roe deer antlers (Capreolus capreolus L.). Prz. zool. 29, 3: 361-368 [In Polish with English summ.].

MIERZWA A., see MICHALCZYK K. et al.

MIERZWA J., see MICHALCZYK K. et al.

MOLENDA O. [Dept. Anim. Anat., Agric. Acad., Kożuchowska 1/3, 51-631 Wrocław]: Szczątki kostne świni (Sus scrofa f domestica) z wczesnośredniowiecznych stanowisk archeologicznych we Wroclawiu - Bone remains of domestic pig (Sus scrofa f. domestica) from early medieval archaeological excavations in Wroclaw. Roczn. Akad. roln. Poznań 164, archeozool. 10: 25-42 [In Polish with English and Russ. summ.].

MUSZYŃSKI M., see BOCHEÑSKI Z. et al.

NADACHOWSKI A. (1), see ALEXANDROWICZ S. W. et al.

NADACHOWSKI A. (2), see BOCHEŃSKI Z. et al.

NOWAK G. [Dept. Exper. Pathol. Anim., Inst. Plant Gen., P. A. Sci., Grunwaldzka 250, 60-166 Poznań]: Jodothyronine content in the pig thyroid gland. Comp. Biochem. Physiol. A, 80, 2: 183-186.

NOWAK I., URBANIK-BRZOZKA A., TWARDOWSKI J. \& ANZENBACHER P., 
[Inst. Zool., Jagiell. Univ., Karasia 6, 30-060 Kraków]: The rhythm of acid phospha. tase activity in adult and old rat livers. Folia biol. 33, 3-4: 159-166 [Polish and Russ. summ.].

OSWALD C. \& JACZEWSKI Z.: Nieco danych o jeleniu białowargim (Cervus albirostris Przewalski, 1883) - Some data about Thorold's deer (Cervus albirostris Przewalski, 1883). Prz. zool. 29, 2: 215-225 [In Polish with English summ.].

PARUSEL J. B. [Babia Góra Nat. Park, 34-223 Zawoja]: Występowanie niedźwiedzia brunatnego Ursus arctos L. w pasmach Babiej Góry, Jałowca i Policy w Beskidzie Wysokim - The occurrence of brown bear Ursus arctos L. in Babia Góra, Jałowiec and Polica ranges (High Beskid Mts.). Acta zool. cracov. 29, 4: 53-68 [In Polish with English summ.].

PREJZNER-MORAWSKA A., see URBANOWICZ M. \& PREJZNER-MORAWSKA A. PRZYBYLSKA B., see WYRZYKOWSKI Z. et al.

PUCEK M., see KLEVEZAL G. A. et al.

REMI J., see MICHALSKI J. \& REMI J.

ROMANKOW-ŻMUDOWSKA A. [Inst. Plant Protect., Miczurina 20, 60-318 Poznań]: Metodyka badania nowych rodentycydów - Investigation methods of new rodenticides. Pr. nauk. I. O. R. 27, 1: 97-705 [In Polish with English and Russ. summ.]. ROMANOWSKI J. [Dept. Ecol. P. A. Sci., Dziekanów Leśny, 05-092 Łomianki]: The diet of stray dogs in the suburbs of Warsaw. Rev. Ecol. (Terre Vie) 40: 203-204.

RUPRECHT A. L. (1) [Mammals Res. Inst., P. A. Sci., 17-230 Białowieża]: Dalsze możliwe stanowiska tchórza stepowego Mustela eversmanni Lesson, 1827, w Polsce - Further possible stations of Mustela eversmanni Lesson, 1827, from Poland. Prz. zool. 29, 1: 103-104 [In Polish with English summ.].

RUPRECHT A. L. (2), see CZECZUGA B. \& RUPRECHT A. L.

RUPRECHT A. L. (3), see FEDYK S. \& RUPRECHT A. L.

RUPRECHT A. L. (4), SE HAITLINGER R. \& RUPRECHT A. L.

RUPRECHT A. L. (5), see WOLSAN M. et al.

RUPRECHT A. L. \& BUSZKO S.: Kamionka Martes foina (Erxleben, 1777) w zachodniej części Puszczy Białowieskiej - Stone marten, Martes foina (Erxleben, 1777) in western part of the Białowieża Primeval Forest. Prz. zool. 29, 1: 104-108 [In Polish with English summ.].

RYDLEWSKI J., see ALEXANDROWICZ S. W. et al.

RYNKOWSKA E., see CZEKAŃSKI M. et al.

RYZEWSKI J., see GRĄBCZEWSKA E. et al.

RZEBIK-KOWALSKA B. [Inst. Syst. \& Exp. Zool., P. A. Sci., Sławkowska 17, 31-016 Kraków]: Records of Suncus etruscus in Algeria. Acta Zool. Fennica 173: 225-226.

SAWICKA-KAPUSTA K. [Dept. Anim. Ecol., Jagiell. Univ., Karasia 6, 30-060 Kraków]: Lead accumulation in the postnatal development of the laboratory mouse. Zesz. nauk. Filii UW 48, Biol. 10: 119-123 [Polish summ.].

SCHMIDT K., see KASZUBA S. \& SCHMIDT K.

SIKORSKA-PIWOWSKA Z., KUKWA A., ŁUKASZEWSKA-OTTO H., KOZŁOWSKI P., KRYST-WIDŹGOWSKA T. \& GIZA A. [Dept. Anat., Med. Acad., Chałubińskiego 5, 02-004 Warszawa]: The carotid canal in Rhesus monkey (Cercopithecidae). Folia morph. 44, 1: 33-38 [Polish summ.].

SIUDA A., see ŻUROWSKI W. \& SIUDA A.

SEAWETA R. \& LASKOWSKA-KLITA T. [Inst. Genet. \& Anim. Breed., P. A. Sci., Jastrzębiec n/Warsaw, 05-551 Mroków]: Glutathione content in the semen of bulls of the lowland black-white breed. Acta physiol. pol. 36, 2: 107-111. 
SOBOCIŃSKI M. (1) [Dept. Anim. Anat., Agric. Acad, Wojska Polskiego 71c, 60-625 Poznań]: Szczątki kostne ssaków domowych z wykopalisk w Gieczu - Bone remains of domestic animals from excavations in Giecz. Roczn. Akad. roln. Poznań 164, archeozool. 10: 59-86 [In Polish with English \& Russ. summ.].

SOBOCIŃSKI M. (2): Szczątki kostne ssaków dzikich $z$ wykopalisk w Gieczu Bone remains of wild mammals from excavations in Giecz. Roczn. Akad. roln. Poznań 164, archeozool. 10: 43-58 [In Polish with English and Russ, summ.].

SOBOCIŃSKI M. (3): Szczątki kostne z osad ludności kultury ceramiki wstęgowej na Kujawach (Ze studiów nad rozwojem kultur wstęgowych na Kujawach) - Animal bone remains of band pottery culture settlements in Kujawy (From studies on the development of band pottery cultures in Kujawy). Roczn. Akad. roln. Poznań 164, archeozool. 10: 87-127 [In Polish with English and Russ. summ.].

SOBOCIŃSKI M. \& KIERKOWSKA M.: Szczątki kostne świni (Sus scrofa $f$. domestica) i dzika (Sus scrofa L., 1758) z wczesnośredniowiecznych stanowisk archeologicznych na Kujawach - Bone remains of pig (Sus scrofa f. domestica) and wild boar (Sus scrofa L., 1758) from early-medieval archaeological sites in Kujawy. Roczn. Akad. roln. Poznań 164, archeozool. 10: 129-151 [In Polish with English and Russ. summ.].

STROZIK E. [Inst. Breed. \& Techn. Anim. Prod., Warsaw Agric. Univ., Przejazd 4, 05-840 Brwinów]: Heritability and postnatal effect of maternal behaviour activities and maternal behaviour test result in mice of outbred stock. Gen. pol. 26, 2: 261-265 [Polish and Russ. summ.].

STWORZEWICZ E., see BOCHEŃSKI Z. et al.

SUMIŃSKI E., see KANIA B. F. et al.

SZATKOWSKI E., see SZTEYN S. et al.

SZOSTAKIEWICZ-SAWICKA H., see KUBASIK A. \& SZOSTAKIEWICZ-SAWICKA $\mathrm{H}$.

SZTEYN S. [Dept. Vertebr. Anat., Teachers Train. Coll., Żołnierska 14, 10-561 Olsztyn]: Nucleus olivaris inferior of the European bison. Acta theriol. 30, 5: 131-138 [Polish summ.].

SZTEYN S., SZATKOWSKI E. \& JATCZAK B.: Motor nuclei of medulla oblongata in the European bison. Acta theriol. 30, 26: 423-433 [Polish summ.].

SZYLARSKA-GOŹDŹ E., see GROMADZKA-OSTROWSKA J. et al.

SZYLARSKA-GOŹDŹ E. GROMADZKA J. [Physiol. Lab., Warsaw Zool. Garden, Ratuszowa $1 / 3,03-461$ Warszawa]: Badania nad cyklami płciowymi i ich sezonową zmiennością $u$ samic szynszyla małego (Chinchilla ianiger) - The study of the sexual cycles and their seasonal fluctuations in female chinchillas (Chinchilla laniger). Zwierzęta lab. 21, 1(1984): 31-43 [In Polish with English summ.].

SZYNDLAR Z., see BOCHEŃSKI Z. et al.

SMIEŁOWSKI J. (1) [Inst. Appl. Zool., Agric. Acad., Wojska Polskiego 71c, 60-625 Poznań]: Rozmnażanie jaguara Panthera onca (Linnaeus, 1758) w warunkach zoo - Breeding jaguars Panthera onca (Linnaeus, 1758) in the Zoo environment. Roczn. Akad. roln. Poznań 163, zootechn. 33: 77-84 [In Polish with English and Russ. summ.].

SMIEŁOWSKI J. (2): Chów wydry Lutra lutra (Linnaeus, 1758) w polskich ogrodach zoologicznych - Breeding of otter Lutra lutra (Linnaeus, 1758) in Polish Zoological Gardens. Roczn. Akad. roln. Poznań 163, zootechn. 33: 85-91 [In Polish with English and Russ. summ.].

SWIEZYYNSKI K., see LASOTA-MOSKALEWSKA A. et al.

TOPIŃSKI P. \& BIERNACKA J. [Inst. Ecol., P. A. Sci., Dziekanów Leśny, 05-150 Łomianki]: Wstępne efekty introdukcji bobra europejskiego Castor fiber L. W lasach Puszczy Kampinoskiej - Initial effects of the introduction of the beaver into Kampinoska Forest. Parki nar. Rez. przyr. 6, 2: $71-83$ [In Polish with English summ.]. 
TWARDOWSKI J., see NOWAK I. et al.

URBANIAK-BRZOZKA A., see NOWAK I. et al.

URBANOWICZ M. \& PREJZNER-MORAWSKA A. [Dept. Anat., Med. Acad., Dębinki $1,80-211$ Gdańsk]: The triceps surae muscle in platyrrhine monkeys. Folia morph. 44, 2: 153-162 [Polish summ.].

WAGNER A. [Dept. Comp. Anat., Jagiell. Univ., Karasia 6, 30-060 Kraków]: Polimorfizm genetyczny koloru i dlugości sierści w populacjach kota domowego ( $\mathrm{Fe}$ lis catus L.) - The genetic coat colour and hair length polimorphism in populations of the domestic cat (Felis catus L.). Prz. zool. 29, 1: 87-102 [In Polish with English summ.].

WALICKI J., see CZEKAŃSKI M. et al.

WALKOWA W., see CHEŁKOWSKA H. et al.

WĄGIEL J., see GAŹDZIK T. et al.

WOLANSSKA L., see DOBROWOLSKA A. \& WOLAŃSKA L.

WOLSAN M., RUPRECHT A. L. \& BUCHALCZYK T. [Inst. Syst. \& Exp. Zool, P. A. Sci., Sławkowska 17, 31-016 Karków]: Variation and asymetry in the dentition of the pine and stone martens (Martes martes and Martes foina) from Poland. Acta theriol. 30, 3: 79-114 [Polish summ.].

WOŁK E. (1) [Mammals Res. Inst., P. A. Sci., 17-230 Bialowieża]: Hematology of a hibernating rodent - the northern birch mouse. Acta theriol. 30, 22: 337-348 [Polish summ.].

WOEK E. (2): Hematology of the early postnatal deveiopment in free-ranging mammals. Zesz. nauk. Filii UW 48, Biol. 10: 31-41 [Polish summ.].

WOEK K., see WOJCIK J. M. \& WOŁK K.

WOEOSZYN D., GUEMEZ J. C. \& WOEOSZYN B. W. [Inst. Syst. \& Exp. Zool., P. A. Sci., Sławkowska 17, 31-016 Kraków]: New locality record of La Laguna mountain shrew, Sorex ornatus lagunae Nelson et Goldman, 1909, in Cape region of Baja California, Mexico. Acta theriol. 30, 8: 157-160.

WOEOSZYN B. W. (1), see ALEXANDROWICZ S. W. et al.

WOEOSZYN B. W. (2), see WOEOSZYN D. et al.

WOJCIK J. M. \& FEDYK S. [Mammals Res. Inst., P. A. Sci., 17-230 Białowieża]: A new chromosome race of Sorex araneus L. from Northern Poland. Experientia 41, 6: $750-752$.

WOJCIK J. M. \& WOEK K.: The daily activity rhythm of two competitive rodents: Clethrionomys glareolus and Apodemus flavicollis. Acta theriol. 30, 14: 241-258 [Polish summ.].

WYROST P. \& CHRZANOWSKA w. (1) [Dept. Anim. Anat., Agric. Acad., Kożuchhowska $1-3,51-631$ Wrocław]: Jeleń (Cervus elaphus L., 1758) z terenu Ślaska w świetle badań kostnych materiałów wykopaliskowych - Red deer (Cervus elaphus L., 1758) from the region of Silesia in the light of bone investigations of excavation material. In "Dawna fauna Sląska $w$ świetle badań archeozoologicznych", Ed. P. Wyrost, Pr. Kom. archeol. PAN Wrocław 3: 103-132 [In Polish with. English summ.].

WYROST P. \& CHRZANOWSKA W. (2): Sarna (Capreolus capreolus L., 1758) z terenu Sląska w świetle badań kostnych materiałów wykopaliskowych - Roe deer (Capreolus capreolus L., 1758) from the region of Silesia in the light of bone investigations of excavation material. In "Dawna fauna Sląska w świetle badan archeologicznych", Ed. P. Wyrost, Pr. Kom. archeol. PAN Wroclaw 3: 133-155 [In Polish with English summ.].

WYROST P. \& CHRZANOWSKA W. (3): Ssaki średniowiecznej fauny Sląska w świetle badań archeozoologicznych - Mammals of the mediaeval fauna of Silesia in the light of archeozoological investigations. In "Dawna fauna Sląska w świetle badań archeozoologicznych", Ed. P. Wyrost, Pr. Kom. archeol. PAN Wrocław 3: 59-101 [In Polish with English summ.]. 
WYRZYKOWSKA K., see WYRZYKOWSKI Z. et al.

WYRZYKOWSKI Z, WYRZYKOWSKA K. \& PRZYBYLSKA B. [Inst. Basic Vet. Sci., Agric. \& Technol. Acad., Kortowo Bl. 37, 10-957 Olsztyn]: Morphologic and cytochemical studies of the pig's pinealocytes with special consideration to the cytoplasmic dense bodies. Folia morph. 44, 3-4: 167-174 [Polish summ.].

ZALEWSKA B. (1), see GROMADZKA-OSTROWSKA J. \& ZALEWSKA B.

ZALEWSKA B. (2), see GROMADZKA-OSTROWSKA J. et al.

ZALEWSKA B. (3), see GROMADZKA-OSTROWSKA et al.

ZALEWSKA B. (4), see JAKUBÓW K. et al.

ŻUK L. [Dept. Paleozool., Wrocław Univ., Sienkiewicza 21, 50-335 Wrocław]: Ewolucja funkcjonowania uzębienia Ursus wenzensis Stach i innych gatunków rodzaju Ursus - Evolution of the teath function in Ursus wenzensis Stach and in other species of genus Ursus. Prz. zool. 29, 1: 109-115 [In Polish with English summ.]. ZUUROWSKI W. \& SIUDA A. [Inst. Gen. \& Anim. Breed., P. A. Sci., Res. St. Popielno, 12-222 Wejsuny]: Ochrona bobra w rejonie Kanału Mazurskiego - Protection of the beaver in the region of the Mazurski Canal. Parki nar. Rez. przyr. 6, 2: 57-69 [In Polish with English summ.].

\section{SUBJECT INDEX 1}

\section{Evolution and genetics}

Fedyk \& Ruprecht - 1; Gębczyński; Kobryńczuk - 1; Michalski \& Remi; Strózik; Wagner; Wójcik \& Fedyk; Zuk.

\section{Morphology}

Frąckowiak (1984); Galert; Gaździk et al.; Gienc \& Kuder; Jaczewski \& Oswald; Klevezal et al.; Knasiecka (1984); Kobryńczuk - 1; Kot; Kozłowski; Kubasik \& Szostakiewicz-Sawicka; Kubasik-Juraniec \& Szostakiewicz-Sawicka (1984); Kuder; Liro; Michalczyk et al.; Michalski \& Remi; Moryś et al. (1984); Pospieszny (1984); Siwek \& Osemlak (1984); Sikorska-Piwowska et al.; Stefanowski (1984); Szteyn; Szteyn et al.; Szostakiewicz-Sawicka \& Grzybiak (1984); Urbanowicz \& Prejzner-Morawska; Wolsan et al.; Wyrost \& Chrzanowska - 1, 2; Wyrzykowski et al.

\section{Physiology}

Cygan; Czeczuga; Czeczuga \& Ruprecht; Dobrowolska \& Wolańska; Gẹbczyński \& Gębczyńska; Grąbczewska et al.; Grodziński; Gromadzka-Ostrowska \& Zalewska; Gromadzka-Ostrowska et al.; Gromadzka-Ostrowska et al.; Harmata; Jaczewski - 1; Jakubów et al.; Kania et al; Król; Malzahn; Nowak; Nowak et al.; Slaweta \& Laskowska-Klita; Szylarska-Góźdź \& Gromadzka; Wołk - 1, 2; Wójcik \& Wolk.

\section{Reproduction, Sex, Hybrydisation}

Kowalski - 1; Krzywiński; Sławeta \& Laskowska-Klita; Smielowski $1,2$.

5. Development

Gaździk et al.; Gębczyński \& Gębczyńska; Klevezal et al.; Kozakiewicz A.; Kozłowski; Pospieszny (1984); Sawicka-Kapusta; Wołk -2 .

\section{Ecology, Biology and Conservancy}

Bobek et al. (1984); Bujalska - 1, 2; Chełkowska et al.; Chwedeńczuk (1984); Czekański et al.; Dobrowolska \& Wolańska; Gliwicz; Graczyk; Grodziński; Harmata - 1; Kaleta; Kozakiewicz M.; Krzanowski; Liro; Malzahn; Męczyński - 1, 2; Oswald \& Jaczewski; Pucek (1984); Romankow-Żmudowska; Romanowski; Sawicka-Kapusta; Strózik; Wierzbowska (1984); Wójcik \& Wołk; Zurowski \& Siuda.

1 Year of publication is given after the author's name only for papers published in 1984. It is omitted where it is 1985 . 
7. Distribution, Fauna and Systematics, Palaeontology

Alexandrowicz et al.; Chrzanowska - 1; Czekański et al.; Fedyk \& Ruprecht; Gawlikowski \& Stępień (1984 1, 2); Graczyk; Haitlinger; Haitlinger \& Ruprecht; Harmata - 3; Kaszuba \& Schmidt; Kobryń \& Kobryńczuk Kobryń \& Serwatka (1984); Kobryń et al. (1984); Lasota-Moskalewska (1984); Lasota-Moskalewska et al.; Makowiecki - 1, 2; Męczyński - 1; Molenda (1984 - 1, 2); Molenda; Parusel; Romanowski (1984); Ruprecht - 1; Rup-

Accepted August 12, 1986.

Mammals Research Institute, Polish Academy of Sciences, 17-230 Białowieża, Poland recht \& Buszko; Rzebik-Kowalska; So bociński $(1984-1,2)$; Sobociński 1, 2, 3; Sobociński \& Kierkowska; Sobociński \& Suchowera-Kobryńska (1984); Sobociński \& Swiderska (1984); Stępień-Gawlikowski (1984 - 1, 2); Topiński \& Biernacka; Wołoszyn et al.; Wyrost \& Chrzanowska $-1,2,3$.

8. Parasites, Epidemiology and Pathology

Beaucournu \& Kowalski; Demiaszkiewicz; Haitlinger; Haitlinger \& Ruprecht; Kingston \& Bobek. 